\title{
Sciendo
}

\section{Understanding the Nordic Gender \\ Diversity Paradox}

\section{Inga Minelgaite}

School of Business, University of Iceland

Gimli 101,

Reykjavík 102, Iceland

Email: inm@hi.is

Berit Sund

Nesodden, Norway

Email: berit.sund@icloud.com

Jelena Stankeviciene

Department of Financial Engineering, Faculty of Business Management, Vilnius Gediminas Technical University

Sauletekio al. 11,

Vilnius 10221, Lithuania

Email: jelena.stankeviciene@vgtu.It

\begin{abstract}
Norway and Iceland consistently top global gender equality rankings and pioneer the introduction of various measures for increased gender diversity. Still, actual gender diversity in toplevel positions is lacking. This article seeks to better understand the contradiction between gender equality as a value and the actual lack of gender diversity and presents a conceptual model built of existing literature, which draws on potential differences between values held at the societal level and the individual level, and subsequent consequences for attitudes to diversity and diversityimpacting behaviors. Conceptual propositions are set forth that can be developed into a testable hypothesis.
\end{abstract}

Keywords: gender equality, gender diversity, gender in leadership, gender quotas, individual-level values, societal-level values 


\section{Introduction}

Gender diversity is generally believed to be an important goal for organizations, and different solutions have been tried to bring it about. Consistently ranking high on various gender diversity indexes, the Nordic countries are often looked to for advice in this regard. For example, Norway's introduction of gender quotas on corporate boards has triggered debates across the world regarding the use of similar measures, with several countries following Norway's example (Teigen, 2012). The present article seeks to provide a somewhat more nuanced picture of gender diversity in these countries by taking Norway and Iceland as a point of departure. These two countries were chosen as they both have been pioneers in gender diversity, although through different measures and at different times: Norway was the first country in the world to implement a gender quota for corporate boards and Iceland was the first country in the world to elect a female president in addition to implementing gender quotas for boards. As such, Norway and Iceland can be considered role models for other countries seeking a positive shift in gender equality. However, even in these countries, gender diversity in top-level positions is still lacking (Rafnsdottir et al., 2015; Halrynjo et al., 2015). Researchers from different disciplines have tried to explain why this is the case (Sund, 2015), including viewing it as a consequence of incongruence between gender roles and job roles (e.g., Eagly et al., 2000; Eagly \& Karau, 2002); as a result of the "doing" of gender (e.g., West \& Zimmerman, 1987; Gherardi \& Poggio, 2001; Pesonen et al., 2009); as a cognitive shortcoming that makes it easier to hire and promote people similar to oneself (e.g., Chattopadhyay et al., 1999), and as a consequence of power or a lack thereof (e.g., Huse \& Solberg, 2006). The dominance of men in top-level positions is by no means a purely Nordic phenomenon: the tendency is the same globally. The Global Gender Gap Index of 2015 presented an interesting picture in this regard, as it revealed that the 145 countries covered had closed almost $96 \%$ of the gap between men and women in various health outcomes, $95 \%$ in educational attainment, but only $59 \%$ of the gap between the genders in economic participation and $23 \%$ in political empowerment. Thus, the topic of women's participation in the economy and business continues to be relevant worldwide. Women remain under-represented in high-paying positions with power. And while this tendency can be found across the globe, it is particularly interesting that the Nordic countries, with their progressive gender policies, have not been able to bring about actual gender diversity. Many studies have related societal culture with gender (in)equality, however, few studies 
focus on exploring how societal culture actually influences gender equality processes (Cheung \& Chan, 2007).

It is on this background that we build a theoretical model for understanding why there is a gap between the apparent value ascribed to gender equality in the Nordic countries and the actual gender diversity in top-level positions. In doing so, we seek to contribute to the general management literature-and, importantly, also to the greater gender equality discussion in organizations. This model builds on research on societal-level and individual-level values, where a key takeaway is that while values at the societal (national) level certainly influence values at the individual level, a perfect overlap between the two types is not necessarily the case. We propose that accounting for values at both levels rather than only the societal level, which generally seems to be the case in discussions involving Nordic gender equality, opens up for an understanding of the possibility that not everyone within the Nordic countries actually view gender equality as an important value. The model then suggests that there is no direct relationship between individuallevel values of gender equality and actual gender diversity in organizations, but that this relationship is mediated by the attitudes to diversity that individuals hold. In short, the proposed model offers a more fine-grained understanding of the nature of gender equality values and resulting gender diversity. The article closes with a discussion of practical implications resulting from the model along with suggestions for future research of both empirical and theoretical nature.

\section{Gender diversity in Norway and Iceland}

The question of why gender equality in organizations matters can be approached from different perspectives, ranging from "soft" and concerned with ethics and justice to "hard" and concerned with the bottom line. From a business ethics point of view, a focus on gender equality can indicate an organization's social responsiveness (Kelan, 2008; McCabe et al., 2006), and it has a moral aspect also in terms of justice and equal rights for all (Billing $\&$ Alvesson, 1989) and social fairness (Noon, 2007). From a financial point of view, efficiency and differentiation in the management of human resources is one of the only arenas on which organizations can achieve sustained competitive advantage (Wright et al., 1995). While research tends to focus on the moral or social desirability aspects rather than monetary gains of 
gender diversity (Robinson \& Denchant, 1997; Kossek et al., 2002), some contributions do focus on shareholder gains resulting from good management of human capital in terms of drawing on a wide pool of resources rather than just a portion of it (Carter et al., 2003; Wright et al., 1995; Randøy et al., 2006).

\subsection{Gender diversity in Norway}

The Nordic countries have a great deal of cultural and social similarity. In particular, they are strong welfare states with generous public sectors and a focus on equality, including gender equality (Aronsson, 2010). This backdrop of egalitarianism is arguably needed for understanding the introduction of the Norwegian gender quota in 2006, which made Norway the first country in the world to promote gender diversity on the boards of public limited companies (PLCs) through legislation. The law requires PLCs to have at least $40 \%$ of each gender on their boards and has gained a great deal of international media attention (Strøm, 2015). The example of Norway has had a certain isomorphic effect across borders, with a range of other countries (including Iceland, Belgium, Finland, France, Italy, Kenya, the Netherlands, and Israel) introducing similar quotas enforced through various forms of penalties (Terjesen et al., 2014; Bertrand et al., 2015). As Terjesen et al. (2014) note, such gender quota legislation has important ethical aspects: before such legislations are introduced, women may be underrepresented despite their equal competence. But with the introduction, it is possible that some unqualified women receive board appointments. These ethical considerations reflect research on the effects of the gender quota, where the results are mixed. Seierstad and Opsahl (2011) observe that the quota has not translated into a larger number of women taking on board positions; these positions are filled from a small pool of women with multiple board memberships. Ahern \& Dittmar (2011) find a significant drop in stock price and deterioration in operating performance in response to the quota, possibly resulting from younger and less experienced boards. Matsa and Miller (2011), on the other hand, compare Norwegian companies affected by the quota with similar companies in other Scandinavian countries without quotas, and find that the Norwegian companies seem to have a stronger long-term perspective with regard to workforce reductions, but simultaneously reduced short-term profits. In short, the question of achieving gender equality through quotas is not simple but has pros and cons attached to it depending on the aims and goals one hopes to realize. Nevertheless, the Norwegian gender quota can be viewed as a manifestation of the importance placed on gender equality in the 
Norwegian culture, alongside with other government legislation focusing on gender equality such as the Norwegian Gender Equality Act of 1978 and the introduction of the world's first gender equality ombudsman in 1979 (NOU 2012:15).

While Norwegians have viewed themselves as champions of gender equality work over the past couple of decades (Andreassen \& Folkenborg, 2002), the effect of the board quota has not spilled over to high-level organizational positions in general; women remain underrepresented there (Bertrand et al., 2015; Andreassen \& Folkenborg, 2002). The Global Gender Gap Report of 2016 reflects this: Norway's high ranking (number 3 out of 144 countries) indicates a high level of general gender equality, but when it comes to women's participation in senior positions, in particular, Norway's ranking drops to number 39 (GGG, 2016). In 2013, only $16 \%$ of private limited company CEOs were women (SN, 2015). And within the 19 largest public companies in Norway, there were no female CEOs (ILO, 2015). Norway has high labor force participation, but the labor market remains gender segregated with women dominating the public sector and part-time positions (SN, 2015). In short-gender diversity in high-paying jobs with status and influence has not been achieved in Norway.

\subsection{Gender diversity in Iceland}

Iceland has long been regarded as a highly egalitarian state. In 2009, women filled $42.9 \%$ of the national government seats (Centre for Gender Equality, 2012), and after the 2016 election, the country continues to have one of the world's largest representations of women in the political field (Zillman, 2016). As mentioned before, Iceland also has a leading position in the Global Gender Gap Index and has been occupying this position for seven consecutive years. However, despite this, the GGGI report, e.g., from 2016 reveals that the gender pay gap is still high and of concern, and that women remain underrepresented in executive management positions. The main guiding piece of legislation in Iceland regarding gender issues is the Gender Equality Act, which aims to "establish and maintain equal status and equal opportunities for women and men, and thus promote gender equality in all spheres of society. All individuals shall have equal opportunities to benefit from their own enterprise and to develop their skills irrespective of gender" (Act on Equal Status and Equal Rights of Women and Men, 10/2008, p. 1). This aim has been achieved in some regard. For example, women's participation in the labor market is $77.6 \%$ in Iceland, which is the highest 
among the OECD countries (Centre for Gender Equality, 2012). Women represent $45.5 \%$ of the total labor force. However, while women are almost equally represented in the labor market, boardrooms are still dominated by men (Centre for Gender Equality, 2012). The representation of women on corporate boards of firms has been stable at $22-24 \%$ during the last ten years (Snorrason, 2012). To increase this number, Iceland has implemented gender quotas similar to Norway's. The laws for both public and private limited companies were amended in 2010 to include new requirements to gender representation on boards: companies with over 50 employees are required to include both genders on their boards, and if the number of board members exceeds three, each gender should be represented by at least 40\% (Centre for Gender Equality, 2012). By the end of 2015, 25.9\% of board members in Icelandic companies were women. This is arguably a slow increase in women representation on boards, particularly if we consider that this number in 1999 was 21.3\% (Statistics Iceland, 2016).

By way of summary, the case for the supposedly gender egalitarian countries Iceland and Norway appears to be a significant and paradoxical gap between gender equity in theory and in practice. In the following section, we build a theoretical model that seeks to provide a better understanding of this apparent paradox.

\section{Model and propositions}

Our proposed model, illustrated in Figure 1, incorporates the effects of societallevel values (in this case, gender equality related values) on individual-level values and how these values subsequently impact diversity-related attitudes and behaviors. We will discuss all of these effects in greater detail. The model sheds light on how it can be that the Norwegian and Icelandic societies place great value on gender equality, yet appear to be unable to achieve actual gender diversity in large parts of their business environments-can it be that societal-level values are not directly transferable into individual-level values, and that these values do not necessarily produce gender diversityincreasing behaviors? 
Figure 1. The proposed model: the effects of societal-level and individual-level values on attitudes to diversity and diversityimpacting behaviors.

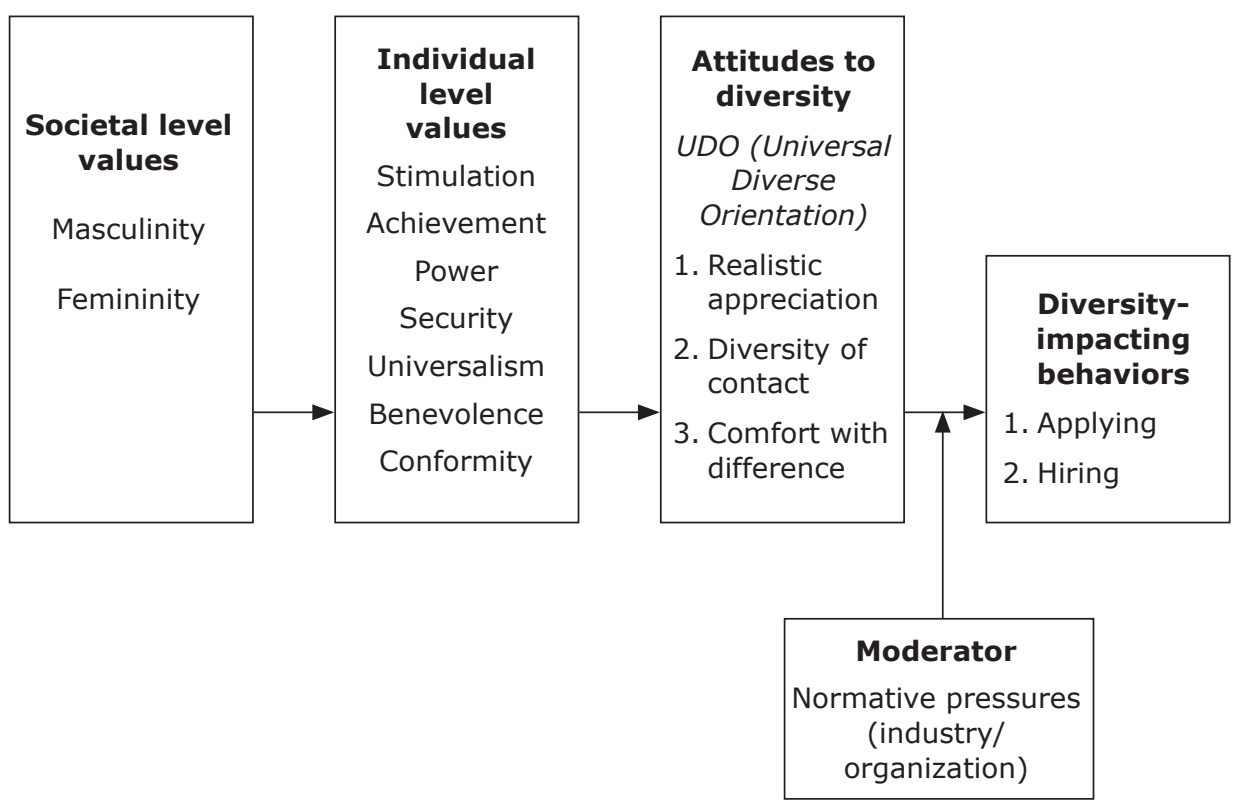

\subsection{Societal-level values (Masculinity and Femininity) and their effects on individual-level values}

The study of gender (in)equality within a societal cultural setting has received researchers' attention, and the link between society and culture has been established in the literature (Bolzendalh \& Myers, 2004; Hardford, 2005). The common way of approaching this link appears to be by means of cultural dimensions, which can be used for understanding societal values.

When discussing gender equality in the context of societal values in crosscultural research, the probably most referred to and used cultural dimension is Hofstede's Masculinity versus Femininity. This dimension distinguishes societies where gender roles are distinct and "masculine" values dominate (high MAS) from those where gender roles overlap (low MAS) (Hofstede, 1991). In high MAS cultures or organizations, very few women can get higher-level and better-paying jobs, while in low MAS cultures, women can get a more equitable organizational status (Wu, 2006). Hofstede (2001) suggests that the Masculinity v. Femininity dimension has an impact on various aspects 
of life, including social norms, politics and economics, religion, work, family and school. For example, Feminine societies will be relationship-oriented, with a high emphasis on quality of life and relationship with people. These societies will focus on environmental issues and solve conflicts through negotiation. Interestingly, Feminine societies will assign less importance to religion and will typically have both men and women in priests' positions. As might be assumed, Feminine societies will be characterized by a smaller wage gap and a higher number of women in management positions, and a preference for fewer working hours. When it comes to family and school, Feminine societies will be characterized as having a flexible family structure, "acceptance" of both girls and boys crying, and intolerance of fighting, and considering failure to be a minor accident (Hofstede, 2001).

Masculinity v. Femininity is an interesting and relevant cultural dimension in that it has deep historical roots within societies that are unlikely to disappear in the future (Hofstede et al., 1998). Hofstede et al. (1998) provide the synonym of 'Ego/Social' for the Masculinity v. Femininity dimension, indicating the core focus of each side of it: Masculinity is related with ego, competition and individual achievement, while Femininity is concerned with social equality and well-being, hence gender equality.

GLOBE (Global Leadership and Organizational Behavior Effectiveness) is another major research project in cross-cultural management literature that examines societal culture by using dimensions. This multi-phase and multimethod study used nine dimensions to measure societal cultures, one of which is directly related to the gender equality aspect within societies. This dimension is called Gender Egalitarianism and describes the extent to which an organization or a society minimizes gender role differences and gender discrimination. House et al. (2002) indicate that Hofstede's Masculinity v. Femininity corresponds to GLOBE's Gender Egalitarianism and Assertiveness dimensions (the degree to which individuals in organizations or societies are assertive, confrontational, and aggressive in social relationships). Even though the Gender Egalitarianism dimension is useful in cross-cultural leadership research, particularly in management settings, we argue that the GLOBE study's lack of discrimination between societal level and organizational level dimensions might obscure the connection between societal level values, individual level values and individual actions. Hence, further on, we focus on Hofstede's dimensions of Masculinity v. Femininity. Furthermore, existing evidence (e.g., Cheung \& Chan, 2007) already indicates Hofstede's dimensions to be relevant in the context of the gender equality debate. As mentioned above, Iceland and Norway rank high 
in gender equality aspect. These countries are also considered as Feminine countries (low Masculinity) in Hofstede's estimations (Hofstede, n.d.) and hence, congruently with the finding of the Global Gender Gap Index suggest these countries to be inclined towards gender equality.

Olsen (2015) suggests that conceptually and empirically, societal values are distinct from individual-level values (Hofstede, 1980; Schwartz, 1999; Kirkman et al., 2006). However, in research, individual-level operationalizations of value constructs that originally are conceptualized for the societal level tend to be used (Hofstede, 2001; Leung, 2004; Kirkman et al., 2006). Organizational research on societal values has contributed significantly to our increased understanding of the impacts of culture. However, by accounting for values at both the individual and societal levels, organizational scholars will obtain a more complete understanding of how these perceptions are formed (Olsen, 2015). To illustrate the potential utility of considering values at multiple levels, Olsen (2015) puts forth a model that explains how societal and individual values jointly contribute to the formation of individuals' preferences among different rules for the allocation of work rewards. In this article, we apply Olsen's (2015) line of thought connecting societal and individual values and potential actual behavioral outcomes and use it in the different context of gender equality considerations within a cultural frame.

The main idea presented by Olsen (2015) is connecting a particular societal cultural dimension with relevant individual dimensions and then certain behavioral outcomes. Societal values have an indirect effect on behavior via their influence on individual values (Olsen, 2015). Our model is in line with this suggestion and is also congruent with other research (e.g., Schwartz, 1992) suggesting that individual values originate as a response to three necessities common to all individuals: biological needs, requirements for coordinating social interactions, and group survival needs. Individuals choose to deal with these in different ways, resulting in different value structures. Similar social situations, however, tend to prompt some similarities among individuals in the values they hold, likely due to similarities in the experiences that shape their value systems (Rokeach, 1973; Schwartz, 1992; Smith \& Schwartz, 1997). Thus, the values that characterize a society contribute to a social context in which individuals are exposed to and rewarded for the expression of certain individual values that are congruent with the dominant societal values.

Hofstede's model of societal cultural values is a paradigm in cultural research. Similarly, Schwartz's theory of basic values (Schwartz, 2012) 
is probably the most used model when investigating individual value dimensions. Swartz's model of basic values comprises of ten dimensions: Power, Achievement, Hedonism, Stimulation, Self-direction, Universalism, Benevolence, Tradition, Conformity and Security. Seven of these dimensions can be related to gender equality, hence were chosen to be used in our proposed model. Descriptions of these individual values are provided below.

Table 1. Definitions of types of values

\begin{tabular}{|l|l|}
\hline Stimulation & $\begin{array}{l}\text { Excitement, novelty, and challenge in life (daring, a varied } \\
\text { life, an exciting life) }\end{array}$ \\
\hline Achievement & $\begin{array}{l}\text { Personal success through demonstrating competence } \\
\text { according to social standards (successful, capable, ambitious, } \\
\text { influential) }\end{array}$ \\
\hline Power & $\begin{array}{l}\text { Social status and prestige, control or dominance over people } \\
\text { and resources (social power, authority, wealth) }\end{array}$ \\
\hline Security & $\begin{array}{l}\text { Safety, harmony and stability of society, of relationships, and } \\
\text { of self (family security, national security, social order, clean, } \\
\text { reciprocation of favors) }\end{array}$ \\
\hline Universalism & $\begin{array}{l}\text { Understanding, appreciation, tolerance and protection of the } \\
\text { welfare of all people and of nature (broadminded, wisdom, } \\
\text { social justice, equality, a world at peace, a world of beauty, } \\
\text { unity with nature, protecting the environment) }\end{array}$ \\
\hline Benevolence & $\begin{array}{l}\text { Preservation and enhancement of the welfare of people with } \\
\text { whom one is in frequent personal contact (helpful, honest, } \\
\text { forgiving, loyal, responsible) }\end{array}$ \\
\hline Conformity & $\begin{array}{l}\text { Restraint of actions, inclinations, and impulses likely to upset } \\
\text { or harm others and violate social expectations or norms } \\
\text { (politeness, obedient, self-discipline, honoring parents and } \\
\text { elders) }\end{array}$ \\
\hline
\end{tabular}

Source: Bardi \& Schwartz, 2016, p. 1208

By way of summary, existing research on societal-level values and individuallevel values suggests that there is not necessarily a perfect overlap between values at the societal level and at the individual level. Thus, a country may be populated by both people who value gender equality and people who do not, and still be rated highly in terms of gender equality. We set forth the following proposition:

P1: The societal-level value of Masculinity v. Femininity will affect individual-level values of Stimulation, Achievement, Power, Security, Universalism, Benevolence, and Conformity. 


\subsection{The effects of individual-level values on diversity attitudes and behaviors}

While individuals' values encompass their preferences for actions and endstates of existence (Rokeach, 1973; Schwartz, 1996; Allport, 1961), the relationship between values and behavior is rarely direct. Even though numerous empirical studies link values to behavior, overall there is a lack of clarity regarding whether values relate to behavior generally or if some values relate to only some behaviors (Bardi \& Schwartz, 2016). The question of whether there is a clear link between values and behavior is important because if there is not, then there is arguably little point in engaging in efforts to establish or change values in daily conduct (Bardi \& Schwartz, 2016). Schwartz (2017) notes that attitudes usually serve as a mediator in the value behavior. The cognitive hierarchical relationship between values, attitudes, and behaviors (Rokeach, 1973; 1979; Homer \& Kahle, 1988) has received empirical support from a range of studies within social psychology, including environmentally significant behaviors such as recycling and wildlife management (e.g., McCarty \& Shrum, 1994; Nordlund \& Garvill, 2002; Grunert \& Juhl, 1995; Fulton, Manfredo \& Lipscomb, 1996). The rationale underpinning such studies is that values are relatively abstract cognitions not focused on specific objects or situations but desirable endstates and modes of conduct (Fulton, Manfredo \& Lipscomb, 1996). As such, there is not a 1:1 relationship between specific values and behaviors. While a person's values can be considered antecedents to his or her behaviors, the person will often make trade-offs between individual considerations and the long-term gains for the greater society (McCarty \& Shrum, 1994). This means that it may not always be the case that a particular value brings about a certain behavior. The case of environmentally significant behaviors illustrates this well: most people would probably agree that protecting the environment is important, but that does not necessarily translate into behaviors expressive of this value.

In line with this thinking, the conceptual model put forth in this paper posits that the effect of gender equality values on the behavior of people in an organization is mediated by attitudes to diversity. Attitudes to diversity are relevant in this regard because they may increase the likelihood of the display of behaviors relevant to diversity, such as hiring women for top-level leadership positions, and of women applying for such positions or otherwise making themselves available for them in the first place. Having a negative attitude to diversity, on the other hand, may decrease such hiring and 
applying. Attitudes to diversity can be conceptualized by means of universal diverse orientation (UDO), which is defined as "an attitude that recognizes and accepts the differences and similarities among people", including gender (Miville et al., 1999, p. 303; Miville, 1992; Fuertes et al., 2000). UDO is theorized as a composite of cognitive, behavioral and affective components: recognizing and valuing similarities and differences, seeking diversity of interactions with others, and experiencing connectedness (Miville et al., 1999). Viewing diversity as a composite in this manner allows for finegrained insight into the attitude and opens up for the possibility even if an individual has a positive attitude to diversity in that he or she values differences, the individual may still experience feelings of discomfort and anxiety regarding the aspects that are perceived as unfamiliar and different and, subsequently, avoid seeking interactions with diverse others or feeling comfortable with them (Sawyerr et al., 2005). In the case of gender diversity, it may well be that an individual values gender differences but still feels uncomfortable on account of the unfamiliarity.

Thus, consistently with prior theoretical and empirical work on the relationship between values, attitudes, and behaviors, we propose that

P2: The individual-level values will have an effect on attitudes to diversity.

P3: The effect of individual-level values on diversity-related behaviors such as applying and hiring will be mediated by attitudes to diversity.

\subsection{The moderating effect of normative pressures}

Normative pressures to perform certain behaviors can impact the effect of values on behaviors (Bardi \& Schwartz, 2016). Norms serve to inform people of what tends to be approved or disapproved (injunctive norms) and of what is typically done (descriptive norms) (Cialdini et al., 1991), thereby influencing behavior (Cialdini \& Goldstein, 2004). Thus, group norms serve as guidelines for acceptable and unacceptable behavior, and they develop through interactions among the members of the group (Cialdini \& Trost, 1998). Norms develop as a means for group survival and make the behavior of group members more predictable (Feldman, 1984). To the extent that normative pressures may vary by industry or organization, either in favor of gender diversity or against it, we argue that the presence of such norms may moderate the effect of attitudes to diversity on diversity-impacting behaviors. For example, a person may hold values and attitudes conducive 
to gender diversity but works in an industry or organization where local norms discourage the enactment of these values or attitudes. Thus, we put forth the following proposition:

P4: The effect of attitudes on diversity-impacting behaviors will be moderated by normative pressures at the industry and/or organizational level.

\section{Discussion}

The model presented in this paper is developed on the basis of a model outlined in Olsen (2015), which focuses on the connection between societal values and individual-level values in reward allocation preferences. As such, our proposed model extends the model by Olsen (2015) in terms of both its theoretical contribution and its practical applicability and has several implications for researchers and practitioners.

We have presented propositions that can form hypotheses and be empirically tested. It might be possible to draw on existing data in terms of societallevel values, for example, those of Hofstede (1980), but the use of such prior measurements would require the researcher to make sure that value changes have not occurred at this level. In the case of Norway, past research has indicated regional differences in values (Warner-Søderholm, 2010), and this should perhaps also be taken into account if using existing data. The societal-level values can, of course, be measured again, and this would arguably contribute to strengthening our knowledge of cultures outside of the Anglo-American dominance (Chin, 2010). Individual-level values can be measured using existing measures, for example, Schwartz' theory of basic values (Schwartz, 2012). It is again worth emphasizing that while cultural dimensions such as those of Hofstede (2001) and GLOBE (e.g., House, 2002) are useful for comparing cultures with each other and considering how one culture's behavior will be different or similar to another at the societal level, they are not appropriate for application to the individual level and are therefore of limited use for understanding individual behavior. Thus, future research efforts should take care to apply measures that are appropriate for the respective levels of interest.

Testing hypotheses derived from the propositions will contribute to our knowledge of the relationship between societal-level values and individual- 
level values, and of the influence of values on attitudes and behaviors. But more importantly from the perspective of gender equality, such tests should contribute to our understanding of why there appears to be a gap between the value that societies ascribe to gender equality, and actual gender diversity. Better insight on this is sorely needed to move forward the debate on gender equality and diversity. For example, policymakers may benefit from information regarding how much people at the individual level actually care about gender equality. For organizations committed to the gender equality idea, such insight would provide a more tangible map for navigating gender equality in the workplace. It is entirely possible that at present, companies, for example, in Iceland and Norway are somewhat passive in this regard because they repeatedly hear that these countries are the best in gender equality issues. While this may be true from a societal perspective, our model suggests that such values may not be the same at the individual level where behaviors with an actual potential to impact diversity (applying and hiring) are enacted. Thus, organizations may be inadvertently reflecting the discrepancy between being the best in gender equality issues at a societal level and actually dealing with gender equality in the best way possible in that particular country. Better knowledge of the real value ascribed to gender equality at the individual level may also be of great importance as organizations head into the future. Surveys putting the Scandinavian countries at the top of the world in terms of gender equality frequently garner much media attention in these countries, which arguably contributes to a commonly shared image of gender equality as something that has already been achieved. An implicit perception of "we have already dealt with gender equality -it has been achieved" may not be conducive to a continued closing of the gender gap also in Iceland and Norway, for example in the areas of equal pay and representation of women in top leadership and board positions.

Inga Minelgaite, $\mathrm{PhD}$, is an associate professor at the School of Business, University of Iceland. Her main research field is (crosscultural) leadership and gender. Inga has 15 years of experience working in senior and top management positions in various sectors of business and multiple countries.

Berit Sund has a PhD in leadership and works as a management consultant. She is a former postdoctoral researcher and adjunct associate professor at the Norwegian School of Economics. 
Jelena Stankeviciene, $\mathrm{PhD}$, is a professor at the Department of Financial Engineering at Vilnius Gediminas Technical University (Lithuania). Her main research topics include value creation, value engineering, assets and liability management, higher education management. Her latest research is concerned with gender equality, fintech and circular economy.

\section{References}

Act on Equal Status and Equal Rights of Women and Men, no. 10/2008, Act of Parliament, Ministry of Welfare, Iceland, 26.2.2008.

Andreassen, J. \& Folkenborg, K. (2002), Vi vil! Slipp oss til! FAFO Rapport, 318.

Aronsson, P. (2010), 'Uses of the past: Nordic historical cultures in a comparative perspective,' Culture Unbound: Journal of Current Cultural Research, vol. 2, no. 5, pp. 553-563.

https://doi.org/10.3384/cu.2000.1525.10232553

Bertrand, M.; Black, S. E.; Jensen, S. \& Lleras-Muney, A. (2015), Breaking the Glass Ceiling: The Effect of Board Quotas on Female Labor Market Outcomes in Norway, NBER Working Paper, no. 20256.

Billing, Y. D. \& Alvesson, M. (1989), 'Four ways of looking at women and leadership,' Scandinavian Journal of Management, vol. 5, no. 1, pp. 6380. https://doi.org/10.1016/0956-5221(89)90006-7

Bolzendahl, C. I. \& Myers, D. J. (2004), 'Feminist attitudes and support for gender equality: opinion change in women and men, 1974-1988, Social Forces, vol. 83, no. 2, pp. 759-790. https://doi.org/10.1353/ sof. 2005.0005

Campbell, K. \& Mínguez-Vera, A. (2008), 'Gender diversity in the boardroom and firm financial performance,' Journal of Business Ethics, vol. 83, no. 3, pp. 435-451. https://doi.org/10.1007/s10551-007-9630-y

Carter, D. A.; Simkins, B. J. \& Simpson, W. G. (2003), 'Corporate governance, board diversity, and firm value,' Financial Review, vol. 38, no. 1, pp. 33-53. https://doi.org/10.1111/1540-6288.00034

Centre for Gender Equality (2012), Gender Equality Iceland: Information on Gender Equality Issues in Iceland, The Centre for Gender Equality Iceland, Akureyri, Iceland.

Cheung, H. Y. \& Chan, A. W. (2007), 'How culture affects female inequality across countries: an empirical study, Journal of Studies in International Education, vol. 11, no. 2, pp. 157-179. https://doi.org/10.1177/1028315306291538 
Chin, J. L. (2010), 'Introduction to the special issue on diversity and leadership,' American Psychologist, vol. 65, no. 3, p. 150. https://doi.org/10.1037/a0018716

Cialdini, R. B. \& Goldstein, N. J. (2004), 'Social influence: compliance and conformity,' Annu. Rev. Psychol., vol. 55, pp. 591-621.

Cialdini, R. B.; Kallgren, C. A. \& Reno, R. R. (1991), 'A focus theory of normative conduct: a theoretical refinement and reevaluation of the role of norms in human behavior,' Advances in Experimental Social Psychology, vol. 24, pp. 201-234.

https://doi.org/10.1016/S0065-2601(08)60330-5

Cialdini, R. B. \& Trost, M. R. (1998), 'Social influence: social norms, conformity and compliance,' in D. T. Gilbert, S. T. Fiske, \& G. Lindzey (eds.) The Handbook of Social Psychology, Boston, MA: McGraw-Hill, pp. 151-192.

Feldman, D. C. (1984), 'The development and enforcement of group norms,' Academy of Management Review, vol. 9, no. 1, pp. 47-53.

https://doi.org/10.5465/amr.1984.4277934

Fuertes, J. N.; Miville, M. L.; Mohr, J. J.; Sedlacek, W. E. \& Gretchen, D. (2000), 'Factor structure and short form of the Miville-Guzman University-Diversity Scale,' Measurement and Evaluation in Counseling and Development, vol. 33, pp. 157-169.

Fulton, D. C.; Manfredo, M. J. \& Lipscomb, J. (1996), 'Wildlife value orientations: a conceptual and measurement approach,' Human Dimensions of Wildlife, vol. 1, no. 2, pp. 24-47. https://doi. org/10.1080/10871209609359060

GGG (2016), Global Gender Gap Report 2016, World Economic Forum, Geneva, Switzerland.

Grunert, S. C. \& Juhl, H. J. (1995), 'Values, environmental attitudes, and buying of organic foods,' Journal of Economic Psychology, vol. 16, no. 1, pp. 39-62. https://doi.org/10.1016/0167-4870(94)00034-8

Halrynjo, S.; Teigen, M. \& Nadim, M. (2015), 'Kvinner og menn i toppledelsen: ringvirkninger av lovkrav om kjønnsbalanse i bedriftsstyrer?' in Virkninger av kjønnskvotering i norsk næringsliv, Oslo: Gyldendal Akademisk.

Hardford, J. (2005), 'The movement for the higher education of women in Ireland: gender equality or denominational rivalry?' History of Education, vol. 34, no. 5, pp. 497-516. https://doi.org/10.1080/00467600500220713

Hofstede, G., ed. (1998), Masculinity and Femininity: The Taboo Dimension of National Cultures, Cross-Cultural Psychology Series, vol. 3, Thousand Oaks, CA: Sage Publications, Inc. 
Hofstede, G. (n.d.), 'National cultural dimensions.' Retrieved from https:// geert-hofstede.com [accessed Mar 2020]

Homer, P. M. \& Kahle, L. R. (1988), 'A structural equation test of the valueattitude-behavior hierarchy,' Journal of Personality and Social Psychology, vol. 54, no. 4, p. 638. https://doi.org/10.1037/0022-3514.54.4.638

ILO (2015), Women in Business and Management Global Report 2015, International Labour Organization.

Matsa, D. A. \& Miller, A. R. (2013), 'A female style in corporate leadership? Evidence from quotas,' American Economic Journal: Applied Economics, vol. 5, no. 3, pp. 136-169. https://doi.org/10.1257/app.5.3.136

McCarty, J. A. \& Shrum, L. J. (1994), 'The recycling of solid wastes: personal values, value orientations, and attitudes about recycling as antecedents of recycling behavior,' Journal of Business Research, vol. 30, no. 1, pp. 53-62. https://doi.org/10.1016/0148-2963(94)90068-X

McClelland, D. C. (1985), Human Motivation, Glenview, IL: Scott, Foresman.

Miville, M. L. (1992), Measuring and Defining Universal Orientation, Unpublished master's thesis, University of Maryland at College Park.

Miville, M. L.; Gelso, C. G.; Pannu, R.; Liu, W.; Touradji, P.; Holloway, P. \& Fuertes, J. N. (1999), 'Appreciating similarities and valuing differences: the Miville-Guzman Universality-Diversity Scale,' Journal of Counseling Psychology, vol. 46, pp. 291-307.

Noon, M. (2007), 'The fatal flaws of diversity and the business case for ethnic minorities,' Work, Employment \& Society, vol. 21, no. 4, pp. 773-784. https://doi.org/10.1177/0950017007082886

Nordlund, A. M. \& Garvill, J. (2002), 'Value structures behind proenvironmental behavior,' Environment and Behavior, vol. 34, no. 6, pp. 740-756. https://doi.org/10.1177/001391602237244

NOU 2012:15 (2012), Politikk for likestilling, Norges Offentlige Utredninger, Departementenes servicesenter, Informasjonsforvaltning, Oslo, 25.9.2012.

Olsen, J. E. (2015), 'Societal values and individual values in reward allocation preferences,' Cross Cultural Management, vol. 22, no. 2, pp. 187-200. https://doi.org/10.1108/CCM-09-2013-0130

Rafnsdottir, G. L.; Aelsdottir, L.; Didriksdottir, S. \& Einarsdottir, Th. (2015), Women and Men as Business Leaders in Iceland, University of Iceland School of Social Sciences. http://mark.hi.is/sites/mark.hi.is/ files/women_and_men_as_business_leaders_in_iceland_28032016_ ensk_vef.pdf [accessed Mar 2020]

Sagiv, L. \& Schwartz, S. H. (2002), Values, Intelligence and Client Behavior in Career Counseling: A Field Study, Manuscript submitted for publication. 
Sawyerr, O. O.; Strauss, J. \& Yan, J. (2005), 'Individual value structure and diversity attitudes: the moderating effects of age, gender, race, and religiosity,' Journal of Managerial Psychology, vol. 20, no. 6, pp. 498-521.

Schwartz, S. H. (2012), 'An overview of the Schwartz theory of basic values,' Online Readings in Psychology and Culture, vol. 2, no. 1, p. 11. https:// doi.org/10.9707/2307-0919.1116

Schwartz, S. H. (2017), 'The refined theory of basic values,' in S. Roccas \& L. Sagiv (eds.) Values and Behavior: Taking a Cross-cultural Perspective, Cham: Springer International Publishing, pp. 51-72.

Seierstad, C. \& Opsahl, T. (2011), 'For the few not the many? The effects of affirmative action on presence, prominence, and social capital of women directors in Norway,' Scandinavian Journal of Management, vol. 27, no. 1, pp. 44-54. https://doi.org/10.1016/j.scaman.2010.10.002

Snorrason, J. S. (2012), 'Yfirlit um stöðu og áhrif jafnari kynjahlutfalla við stjórnun og í stjórnum fyrirtækja,' Stjórnmál og Stjórnsýsla, vol. 8, no. 1, pp. 93-107. https://doi.org/10.13177/irpa.a.2012.8.1.4

Statistics Iceland (2016), Hlutfall kvenna í stjórnum stórra fyrirtækja stendur í stað milli ára 6.5.2016. Retrieved from https://hagstofa.is/utgafur/ frettasafn/fyrirtaeki/stjornir-og-framkvaemdastjorar-fyrirtaekja/ [accessed Mar 2020]

Sund, B. (2015), 'Just an illusion of equality? The gender diversity paradox in Norway,' Beta, vol. 29, no. 02, pp. 157-183.

Terjesen, S.; Aguilera, R. V. \& Lorenz, R. (2015), 'Legislating a woman's seat on the board: institutional factors driving gender quotas for boards of directors,' Journal of Business Ethics, vol. 128, no. 2, pp. 233-251. https://doi.org/10.1007/s10551-014-2083-1

Warner-Soderholm, G. (2010), Understanding Perceptions of Cultural and Intracultural Societal Practices and Values of Norwegian Managers, PhD dissertation, University of Reading.

Wright, P.; Ferris, S. P.; Hiller, J. S. \& Kroll, M. (1995), 'Competitiveness through management of diversity: effects on stock price valuation,' Academy of Management Journal, vol. 38, no. 1, pp. 272-287. https://doi.org/10.2307/256736

Wu, M. (2006), 'Hofstede's cultural dimensions 30 years later: a study of Taiwan and the United States,' Intercultural Communication Studies, vol. 15 , no. 1 , p. 33 .

Zillman, C. (2016), 'The tiny nation of Iceland is crushing the U.S. in electing female politicians,' Fortune, 31 October. Retrieved from http://fortune. com/2016/10/31/iceland-us-women-in-parliament-congress [accessed Mar 2020] 